\title{
Correlation of Self-Confidence and Student Learning Motivation Against Learning Outcomes of Class X Digital Simulation
}

\section{Popi Radyuli ${ }^{*}$, Indra Wijaya ${ }^{2}$, Ita Ulfina ${ }^{3}$}

${ }^{123}$ Fakultas Keguruan Ilmu Pendidikan Universitas Putra Indonesia "YPTK" Padang

A R T I C L E I N F O

Article history:

Received February

2020

Received in revised

Form 01 March 2020

Accepted 18 April 2020

Available online 30 May

2020

Keywords:

self confidence, learning motivation and learning

outcomes

\section{A B S T R A C T}

This study aims to determine the relationship of trust and learning motivation on learning outcomes of simulation and digital communication in class $X$ students. This type of research is quantitative by using correlational research methods. This research was conducted at SMK Negeri 6 Padang, in November 2019. The population in this study were all grade $X$ students of SMK Negeri 6 Padang. The sampling technique uses proportional random sampling. The sample selected in this study were 228 students from 530 students of class $X$. the result is $r$ count $>r$ table $(0.2733>0.161)$, a positive and significant relationship and continued with the F-count test> FT table $(12.33>1,750)$. 


\section{Introduction}

Self Confidence and Student Learning Motivation greatly affects student learning outcomes. Vocational High School 6 Padang is one of the schools that is trying to produce graduates who are ready to compete in the world of work. In facing these challenges, SMK 6 Padang strives to improve the quality of its graduates through improving learning outcomes.

According to Nana Sudjana (2009:3) student learning outcomes are essentially changes in behavior as a result of learning in a broad sense covering cognitive, affective, and psychomotor fields. Dimyati and Mudjiono (2006: 3-4) also mention learning outcomes are the result of an interaction of learning and teaching. From the student's side, the learning outcome is the end of teaching from the peak of the learning process. In reality what happens in daily practice, many students are still classified as poor learning outcomes. This was obtained from daily test scores less than KKM (Minimum completeness criteria).

Based on observations and observations that I made at SMK N 6 Padang, Complete Minimum Criteria set with a value of 75, and teachers who teach Digital Simulation Subjects are graduates from Padang State University who have been certified in these subjects. The purpose of this study was to determine a positive and significant relationship between self-confidence correlations and student learning motivation on student learning outcomes in digital simulation subjects.

Fatimah (2010: 153-155) suggests several characteristics or characteristics of individuals who have proportional self-confidence are as follows: 1) Believe in your abilities or competencies, 2) Dare to accept and face rejection, dare to be yourself, 3) Have good self-control (not in a stable mood and emotions, 4) Having an internal locus of control (looking at success or failure, and 5) Having a positive perspective on yourself

According to Amyani, (2010: 25) self-confidence is a belief in one's own abilities. Self-confidence is an aspect of human personality that functions important to actualize the potential it has. Without a sense of confidence, many problems arise in humans. Due to self-confidence, a person is able to actualize all his potential. Confidence is needed either by a child or a parent, individually or in groups.

Digital Simulation subjects are subjects that equip students to be able to communicate ideas or concepts through digital media. Digital Simulation subjects for vocational students are tools to communicate ideas through digital presentations. In its function as a tool, these subjects provide mastery skills so students know to use them when needed.

\section{Methods}

This type of research used in this study is quantitative with the method used correlational. In this study, the population was all students of class X in SMK Negeri 6 Padang as many as 530 students with samples This study uses Proportional Random Sampling technique, so that the sample of this research is 228 students.

The higher student motivation will have an impact on student learning outcomes. Motivation can affect business drivers and student achievement. For more details can be seen in Figure 1. Chart conceptual framework.

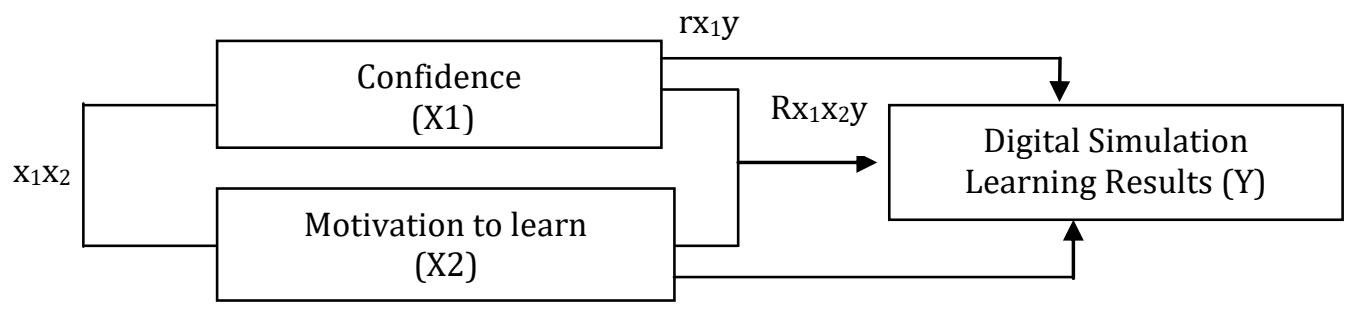

Figure 1: Chart of conceptual framework

Data analysis was performed using a statistical program on a computer namely Microsoft Excel and the SPSSI program, to find out the relationship between the independent variable $(\mathrm{X})$ and the dependent variable (Y). This technique is only implemented if it meets several requirements, namely sample data for each variable normally distributed, homogeneity test, linearity test and hypothesis testing, as below. 
a. Normality test is used to determine whether or not the normal distribution of data is a prerequisite to determine the type of statistics that will be used in subsequent analyzes, the normality test uses the lilliefors test.

b. Regression linearity test with simple regression techniques, to see whether the regression line is linear or not. This test aims to determine the strength of the contribution between variables X1 and $\mathrm{X} 2$ to the variable $\mathrm{Y}$.

Hypothesis testing about the similarity of two averages is done if the data is normally distributed and the two data groups are homogeneous, then in testing the statistical hypothesis the $t$ test is used.

\section{Result And Discussion}

The data display of the basic statistical calculation of the three variables can be seen in table 1 based on the processed data using Microsoft Excel 2010 application.

Table 1. Calculation of Basic Statistics of the Three Variables

\begin{tabular}{ccccc}
\hline No & Statistics & Variable X1 & Variable X2 & Variable $\mathbf{Y}$ \\
\hline 1 & $\mathrm{~N}$ & 228 & 228 & 228 \\
2 & Mean & 105,632 & 98,316 & 81,263 \\
3 & Median & 107 & 98 & 79 \\
4 & Mode & 108 & 93 & 72 \\
5 & Std. Deviation & 9,727 & 9,902 & 10,722 \\
6 & Variance & 94,618 & 98,045 & 114,950 \\
7 & Sum & 16056 & 14944 & 12352 \\
8 & Smallest score & 81 & 61 & 64 \\
9 & Biggest score & 130 & 125 & 100 \\
10 & Range & 49 & 64 & 36 \\
12 & Long Interval Score & 6 & 8 & 4 \\
13 & Class interval & 9 & 9 & 9 \\
\hline
\end{tabular}

a. Normality test

Normality test is done using the Liliefors formula with the results of the test can be seen in table 2 .

Table 2. Normality Test Results

\begin{tabular}{lllllll}
\hline No & Variable & $\mathbf{N}$ & $\mathbf{L}_{\mathbf{o}}$ & $\mathbf{L}_{\mathbf{t}}$ & Comparison & Ket. \\
\hline 1 & $\mathrm{X}_{1}$ & 228 & 0,055 & 0,058 & $\mathrm{~L}_{\mathrm{o}}<\mathrm{L}_{\mathrm{t}}$ & Normal \\
2 & $\mathrm{X}_{2}$ & 228 & 0,057 & 0,058 & $\mathrm{~L}_{0}<\mathrm{L}_{\mathrm{t}}$ & Normal \\
3 & $\mathrm{Y}$ & 228 & 0,056 & 0,058 & $\mathrm{~L}_{0}<\mathrm{L}_{\mathrm{t}}$ & Normal \\
\hline
\end{tabular}

Based on table 5 above it can be seen that the significance score for motivation and learning style on student learning outcomes obtained L0 for the X1 variable of 0.0062 for variable X2 of 0.0008 and for variable Y of -0.0179 . Whereas Lt of 0.0721 was obtained from the critical value of L for the Lilliefors test. Because the result is $\mathrm{L} 0<\mathrm{Lt}$, the sample is said to be normally distributed. Then the linearity test requirements can be done.

b. Linearity test

Linearity test aims to determine whether two variables have a linear relationship or not significantly. Linearity tests are usually used as a prerequisite in correlation analysis or linear regression. The results of data linearity using MS.Excel 2010 can be seen in Table 3.

Table 3. Data Linearity Results

\begin{tabular}{ccccc}
\hline Variable & Sig. & Fcount & Ftable & Criteria \\
\hline $\mathrm{X} 1-\mathrm{X} 2-\mathrm{Y}$ & 0,05 & 265,52 & 1,333 & Linear \\
\hline
\end{tabular}

Based on the linearity test results table above, the value of Thitung $=777.729$, while Ftable $=1.333$ obtained from the distribution table, the value of $F$ at 0.05 significance. Because the value of Fcount is 
greater than Ftable, it can be concluded that there is a significant linear relationship between the equation variables $\mathrm{X} 1$ and $\mathrm{X} 2$ to $\mathrm{Y}$.

\section{c. Hypothesis}

Based on the results of the analysis of research on the calculation of the correlation of Learning Motivation with Learning Outcomes is rcount> rtable $(0.366>0.113)$, Then a $t$ test was conducted between Learning Motivation and learning outcomes tcount> $t$ table $(2.726>1.960)$, so as to obtain positive and significant results between variables X2 (self confidence) and Y (learning outcomes).Based on the calculation of the correlation of self-confidence and motivation to learn with learning outcomes is $r$ count $>\mathrm{r}$ table $(0.273>0.161)$, and an $\mathrm{F}$ test was carried out for both between self-confidence and learning motivation with learning outcomes obtained Fcount> FTabel $(12.33>1.334)$. So it can be said that the relationship in research is said to be positive and significant between self-confidence and learning motivation with learning outcomes of simulation subjects and digital communication of class X students of SMK Negeri 6 Padang. It is stated that the third hypothesis is accepted.So the three hypotheses in this study were first accepted self confidence with learning motivation, the second is learning motivation with learning outcomes and the third is self confidence and learning motivation with learning outcomes. This research is relevant to the thesis of Rona Diana, 2019. Correlation of Learning Interests and Learning Motivation with Learning Outcomes of Digital Simulation Class X Even Semester in SMK Negeri 4 Padang.

\section{Conclussion}

From the research that has been done about the correlation of self-confidence and learning motivation with learning outcomes, it can be concluded that the correlation in research is said to be positive and significant between the correlation of self-confidence and learning motivation with learning outcomes of class X digital simulation subjects, with the meaning of the hypothesis being accepted.

\section{Reference}

Agus Irianto. (2004). Statistics. Jakarta: Kencana.

Anas Sudijono. (2011). Introduction to Educational Evaluation. Jakarta: King of Walipers.

Dimyati \& Mudjiono. (2009). Belajar dan Pembelajaran. Jakarta : Rineka Cipta.

Djamarah, Syaiful Bahri and Aswan Zain. (2011). Teaching and learning strategies. Jakarta: Rineka Cipta.

Husna Asmara. (2015). Educational Profession. Bandung: Alfabeta.

Menrisal, M., \& Utari, E. (2017). The Relationship of Learning Motivation to Student Learning Outcomes of Computer Skills and Information Management (KKPI) (Case Study X of Accounting Department of SMK Nusatama Padang). INFORMATION TECHNOLOGY EDUCATION UPI-YPTK, 4 (1).

Nana Sudjana. (2011). The basics of the teaching and learning process. Bandung: Sinar Baru.

Nasution, S. (2010). Educational Sociology. Jakarta: PT Bumi Aksara.

Nidawati. (2013). Study in a psychological and religious perspective. Pioneer journal, volume 1, no 1, JulyDecember (2013).

Noviyani (2017). Efforts to improve student learning outcomes with the cooperative learning model group investigation type in the thesis foqih the subject matter of Friday prayer vii in mtsn al-hasanah medan. [11] Oemar. (2008: 158). Motivasi Belajar Mengajar. Bandung: Bumi Aksara.

Puspita, L. A. S., Padmadewi, N. N., \& Wahyuni, L. E. (2019). Instructional Teaching Media to Promote Autistic Student's Learning Engagement. Journal of Education Research and Evaluation, 3(2), 58-65.

Radyuli, P., \& Rahmat, V. (2017). Correlation of Learning Discipline and Learning Creativity Against Interest in Learning Information and Communication Technology (ICT). INFORMATION TECHNOLOGY EDUCATION UPI-YPTK, 4 (2). 
Radyuli, P., \& Wijaya, I. (2019). Hubungan Persepsi siswa tentang Keterampilan Guru PLK Tehadap SIkap Belajar Siswa Kelas X di SMKN 1 Pada Pada semester Genap Tahun Pelajaran 2018/2019. JURNAL PTI (PENDIDIKAN DAN TEKNOLOGI INFORMASI) FAKULTAS KEGURUAN ILMU PENDIDIKAN UNIVERSITA PUTRA INDONESIA" YPTK" PADANG, 6(2), 47-55.

Radyuli, P., Sefriani, R. S., \& Qomariah, N. (2019). PEMBELAJARAN INQUIRY MENGGUNAKAN GOOGLE FORM TERHADAP HASIL BELAJAR SIMULASI DAN KOMUNIKASI DIGITAL. EDUKATIF: JURNAL ILMU PENDIDIKAN, 1(2), 56-63.

Slameto (2013). Belajar dan faktor-faktor yang mempengaruhinya. Jakarta: Rineka Cipta

Wage Riska Ani Marja. (2018). The relationship between students' perceptions of teacher teaching skills and learning motivation with student learning outcomes of digital simulation subjects in SMK Negeri 7 Padang even semester of the academic year 2017/2018. 